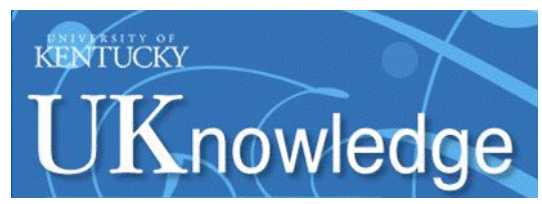

University of Kentucky

UKnowledge

5-16-2017

\title{
The Urban Geographical Imagination in the Age of Big Data
}

John Taylor Shelton

University of Kentucky, taylorshelton@uky.edu

Follow this and additional works at: https://uknowledge.uky.edu/geography_facpub

Part of the Geography Commons, and the Urban Studies Commons

Right click to open a feedback form in a new tab to let us know how this document benefits you.

\section{Repository Citation}

Shelton, John Taylor, "The Urban Geographical Imagination in the Age of Big Data" (2017). Geography Faculty Publications. 13.

https://uknowledge.uky.edu/geography_facpub/13

This Article is brought to you for free and open access by the Geography at UKnowledge. It has been accepted for inclusion in Geography Faculty Publications by an authorized administrator of UKnowledge. For more information, please contact UKnowledge@lsv.uky.edu. 


\section{The Urban Geographical Imagination in the Age of Big Data}

\section{Digital Object Identifier (DOI)}

https://doi.org/10.1177/2053951716665129

\section{Notes/Citation Information}

Published in Big Data \& Society, v. 4, issue 1, p. 1-14.

(c) The Author(s) 2017

This article is distributed under the terms of the Creative Commons Attribution-NonCommercial 3.0 License (http://www.creativecommons.org/licenses/by-nc/3.0/) which permits non-commercial use, reproduction and distribution of the work without further permission provided the original work is attributed as specified on the SAGE and Open Access pages (https://us.sagepub.com/en-us/nam/openaccess-at-sage). 


\title{
The urban geographical imagination in the age of Big Data
}

Big Data \& Society

January-June 2017: 1-14

(C) The Author(s) 2017

Reprints and permissions: sagepub.com/journalsPermissions.nav DOI: $10.1177 / 2053951716665129$ bds.sagepub.com

SAGE

\section{Taylor Shelton}

\begin{abstract}
This paper explores the variety of ways that emerging sources of (big) data are being used to re-conceptualize the city, and how these understandings of what the urban is shapes the design of interventions into it. Drawing on work on the performativity of economics, this paper uses two vignettes of the 'new urban science' and municipal vacant property mapping in order to argue that the mobilization of Big Data in the urban context doesn't necessarily produce a single, greater understanding of the city as it actually is, but rather a highly variegated series of essentialized understandings of the city that render it knowable, governable and intervene-able. Through the construction of new, data-driven urban geographical imaginaries, these projects have opened up the space for urban interventions that work to depoliticize urban injustices and valorize new kinds of technical expertise as the means of going about solving these problems, opening up new possibilities for a remaking of urban space in the image of these sociotechnical paradigms. Ultimately, this paper argues that despite the importance of Big Data, as both a discourse and practice, to emerging forms of urban research and management, there is no singular or universal understanding of the urban that is promoted or developed through the application of these new sources of data, which in turn opens up meaningful possibilities for developing alternative uses of Big Data for understanding and intervening in the city in more emancipatory ways.
\end{abstract}

\section{Keywords}

Critical cartography, mapping, performativity, socio-spatial imaginary, urban geography, urban theory

\section{Introduction}

We currently sit at the intersection of two concurrent and often intersecting trends. First, we are faced with an explosion of interest in, and debates about, cities and urbanization. From the repeated invocation of the (pernicious) fact that over half of the world's population is currently living in cities for the first time in human history, to the emergence of a kind of 'pop urbanism' ranging from the work of Richard Florida and Ed Glaeser, to increasingly public debates about the purported benefits and ills of gentrification, cities are on the agenda (cf. Brenner and Schmid, 2014; Peck, 2016). But the bigness of cities and the discourse surrounding them is matched only by the bigness of data used to understand them. At the same time as cities have taken center stage as an object of concern, we have at our disposal a wider array of data and tools of analysis to help us understand social processes, technologies which are thought to be revolutionary for the way we conduct research and discover previously unforeseen knowledge. Emerging sources of so-called 'Big Data' are seen as enabling new kinds of discoveries unhampered by longstanding theoretical approaches, which only work to constrain our abilities to interpret the data as it actually is (cf. Anderson, 2008).

In concert, these two trends have produced a multibillion dollar a year industry around the provision of so-called 'smart cities' strategies. Whether in the form

\footnotetext{
Department of Geography and New Mappings Collaboratory, University of Kentucky, Lexington, KY, USA

\section{Corresponding author:}

Taylor Shelton, Department of Geography, University of Kentucky, 817 Patterson Office Tower, Lexington, KY 40506, USA.

Email: johntaylorshelton@gmail.com
} 
of mega-projects designed to raise new 'greenfield' smart cities from scratch on coastal areas of South Korea and in the desert of Abu Dhabi, or sell new data analytics capabilities to floundering municipal governments in search of a quick fix for imposed austerity measures, the vision of the smart city combines the emerging enthusiasm for urban life with the tools of Big Data as the means of achieving that goal (cf. Batty, 2012; Halpern et al., 2013; Hollands, 2015; Kitchin, 2014). But, contrary to the dominant discourses about the potential for these new smart city strategies to revolutionize urban governance and management, there isn't a single, linear pathway through Big Data that produces a greater understanding of cities and urban processes, much less inherently better outcomes. Indeed, the dominant framing of the smart city offered up by multinational technology companies remains just one way among many that data is being applied to the understanding of cities (cf. Barns, 2016; Leszczynski, 2016). While the overarching ethos of Big Data promises to provide a single, scientific, more all-encompassing, universal and rational explanation of social processes that is lacking in the broader scholarly literature on cities, the urban geographical imagination produced with the aid of Big Data remains a deeply variegated and often contradictory one. Far from superseding longstanding debates about the nature of the urban, the pluralism of this data-driven urban geographical imagination actually validates contemporary claims within urban geography that "there can be no single urban theory of ubiquitous remit" (Leitner and Sheppard, 2016: 231; see also Robinson and Roy, 2016, for an argument in favor of a more pluralistic approach to urban theory, contra Scott and Storper's, 2015 call for a more unified understanding of the urban based around the ideas of agglomeration and the urban land nexus).

It is worth noting, however, that while 'Big Data' remains the buzzword du jour in the emerging model of data-driven urbanism, in many ways, it is not the 'bigness' of the data that matters. Drawing on Kitchin and McArdle's (2016) typology of Big Data, it isn't even the velocity or 'exhaustivity' of the data in question that makes its application to understanding and planning cities powerful; rather, it is simply important that it is 'data'. I would argue that the dominant discursive framing that valorizes Big Data has actually valorized data of all shapes and sizes - big or small, digital or analog, volunteered or captured, structured or unstructured. As such, data writ-large has been uniquely invested with a substantial power to not only understand but, as I will describe in more detail throughout this paper, also shape our world. So even though we live in an ongoing 'age of Big Data', it is important to broaden our collective view to the way the broader discourse around Big Data has reconfigured a range of dynamics beyond the relatively narrow purview of what we might be able to define with some specificity as distinctly 'Big' Data.

The rest of this paper explores the ways that the city has been (re-)conceptualized through the use of (Big) Data, the kinds of understandings promoted by these uses, and how these understandings shape the kinds of interventions into the urban that emerge from such trajectories. As Rose-Redwood (2012) has argued recently,

"whereas much is known about the history of quanti-
fication as a method of geographical analysis, far less
research has explored how numerical calculation itself
has historically reshaped political practices and the geo-
graphies of everyday life. This distinction between
quantitative methods in geography and the geography
of calculation is significant, because it draws attention
to the way in which calculative rationalities have been
used to refashion the world in their own image" (300)

While this particular characterization constructs a somewhat artificial binary between the ways that quantification is reproduced in scholarship and how quantification reproduces particular kinds of socio-spatial relationships outside of the academic realm, RoseRedwood is certainly right to draw attention to the relative lack of understanding of the broader impacts of quantification and computation. The fact that "[w]e live in an increasingly quantitative world" (Sheppard, 2001: 549) has only further blurred the lines between the 'academic' and the 'practical', as is evidenced by the increasing prominence of Big Data, a discourse and practice largely originating in the private sector, within the academy itself.

In order to understand the interplay between these different domains and their shared mode of data-centric knowledge production, this paper utilizes two distinct case studies in order to highlight how particular uses of data help to refigure our understandings of the urban, and shape the realm of possibilities for interventions into these spaces. While these two vignettes, one focused on the emerging field of 'urban science' and the other on the use of data by a municipal government in order to understand vacant properties, are largely unrelated, they are selected to highlight the diversity of ways that Big Data is deployed in order to understand cities. These two cases operate at different spatial scales, ranging from the macro-scale redefinition of what the urban actually is to a more meso-scale focus on how we understand particular social problems as situated in particular partitionings of urban space, while also operating in different socio-institutional contexts, from scholarly knowledge to urban planning and 
public administration. Indeed, these differences between the two cases are manifest in the ways that they point towards contradictory and competing understandings of urban processes, despite their shared focus on the ostensibly straightforward use of data to reveal unforeseen insights into the city. Ultimately, drawing on work on the performativity of economics, this paper argues that the mobilization of Big Data in the urban context doesn't produce greater understandings of the city as it actually is, but rather produces a series of essentialized understandings of the city that render it knowable, governable and, ultimately, intervene-able in particular ways. Or, in the language of James C Scott (1998), these techniques render the urban 'legible', though not simply to the state, but also simultaneously to citizens and to capital. The understanding of "the urban' promoted by these projects or initiatives is, at best, extremely partial, but yet still powerful and influential. Through the construction of new urban geographical imaginaries, these projects have opened up the space for urban interventions that work to depoliticize urban injustices and valorize new kinds of technical expertise as the means of going about solving these problems, opening up new possibilities for a remaking of urban space in the image of these sociotechnical paradigms.

\section{Pre-histories of Big Data and the city}

Although the emergence of a data-driven urban geographical imagination has become more pronounced in the last several years, it is important to recognize that these particular interminglings of scientific ideology, new technologies and urban problem-solving aren't all that new (Barnes, 2013). Appeals to 'science' and 'quantification' (the two are usually seen to be equivalent) as leading to higher forms of knowledge have a long history in the social sciences in general, and in geography and urban studies in particular, leading Doreen Massey (1999) to argue against the pervasive 'physics envy' in human geography. ${ }^{1}$ Indeed, it is worth noting that some of the earliest forms of quantitative geography emerged out of an adoption of concepts and methods from the emerging field of social physics, which prefigure some of the contemporary trends, and theories, seen in data-driven urban research (cf. Barnes and Wilson, 2014). Even though social scientists of all stripes have long maintained a tense relationship with 'science', as such, some of the earliest social scientific scholarship on the city, conducted by WEB DuBois and Emile Durkheim in the late 19th century emphasized the use of quantitative methods as a way of appealing to the newly emerging standards of a scientific sociology. Similarly, the seminal works of Robert Park, Ernest Burgess, and much of the rest of the Chicago School of Urban Sociology mobilized both the quantitative methodology of social surveys and explanatory metaphors taken from the biological sciences, signaling a longstanding trading zone between the 'hard' sciences and the ostensibly non-scientific study of cities and urban places (Bulmer, 1981; Burgess, 1923; Park, 1936).

The more practically driven work of planning and governing cities has long fallen under similar ways of thinking. And though the emergence and availability of Big Data has brought with it a pervasive sense that "something important has changed" (Graham and Shelton, 2013: 256), as Christine Boyer writes in her history of the planning profession, "[i]nformation has always been the basis of planning" (Boyer, 1986: 276, emphasis added). Were one to go all the way back to the birth of town and regional planning, the importance of such scientific, data-driven approaches to planning can be seen in Patrick Geddes' Camera Obscura and the notion of the civic survey (Hall, 2002). More explicit calls for a scientific approach to planning were being made as early as the second decade of the 20th century, as seen in George Ford's claim that "city planning is rapidly becoming as definite a science as pure engineering" (Ford, 1913: 551). Even when less explicitly stated, urban planning and management have long been shaped by a range of technocratic experts drawing on the powerful discourses associated with the production of a 'scientific' approach to cities inspired by the likes of Frederick Taylor and others (Fairfield, 1994; Schultz and McShane, 1978).

As historian Jennifer Light (2003) has documented, the contemporary application of emerging scientific and technological innovations to the problems of cities is firmly rooted in similar trends in the Cold War era immediately following World War II. Although Light's book predates much of the more recent attention built around the smart cities movement, she makes clear that even for those mid-20th century efforts at a technoscientific approach to planning, "[t]he quest for a coherent science of the city was not new" (Light, 2003: 48). It should be evident that this is even more the case in the present day. That being said, while there is a much longer history to this kind of data-driven urban planning and governance than is often recognized, this tendency has not been entirely persistent over the course of the last century. As LeGates et al. (2009) argue:

\footnotetext{
"The revolution in digital spatial technology has created a new wave of enthusiasm for 'scientific' urban planning - the third in the 100-year history of modern urban planning. Since the beginning of the last century urban planners have alternately embraced rational planning, rigorous scientific methods, and exploitation
} 
of technology, only to reject scientific city planning when the application of the technology and the theory of the day failed to produce the overly optimistic results advocates had promised" (763)

Indeed, one of the strongest statements against these repeated attempts to make the study and planning of cities more scientific came in the form of Douglass Lee's (1973) "Requiem for Large-Scale Models", an excoriation of precisely the type of 'hyper-comprehensive' planning approaches being promoted by contemporary smart cities advocates. And while one of Lee's primary points of contention was that these models were constrained by a lack of available data, a problem it would seem would be substantially less relevant in the present moment, his arguments remain prescient and applicable to the broader scientific modeling impulse being applied to cities in the present day (cf. Batty, 2014; Brömmelstroet et al., 2014). Although practices of quantification have always held a certain power due to their air of objectivity (cf. Porter, 1996), the contemporary moment surrounding Big Data seems relatively novel in that it is data itself that is foregrounded, rather than particular techniques or approaches to analyzing it. Data is increasingly imagined as providing a fundamentally unique and substantive insight into the world around us, regardless of the particular form of data or the particular questions being asked of it.

As these historical examples highlight, both the 'urban' - as a process and ideal-and the 'city' - as a juridical construct and material reality - are always in a process of being re-imagined and re-made through socio-technical practices and processes. The urban as we are able to know it doesn't preexist these forms of knowledge production, but comes into being through them. Inspired by the work of Donald MacKenzie and Timothy Mitchell, among others, the rest of this paper applies the insights of work on the social construction and performativity of the economy to the social construction and performativity of the urban, focusing on how the constitutive discourse and practice of Big Data is reshaping what we understand the essential nature of the urban to be, and therefore, how we imagine ourselves to be able to change it. As Mitchell writes, "[t]he economy came into being as a self-contained, internally dynamic, and statistically measurable sphere of social action, scientific analysis, and political regulation" (Mitchell, 2002: 4); so too is it the case with the urban. Using two vignettes, the following section documents the different ways in which the contemporary focus on data is producing new kinds of representations and understandings of the urban, giving way to different ways of intervening in these spaces.

\section{Unpacking the data-driven urban geographical imagination}

Key to the rethinking of data's role in contemporary processes of urban planning and governance is the recognition that data does not inherently "offer a higher form of intelligence and knowledge that can generate insights that were previously impossible, with the aura of truth, objectivity, and accuracy" (Boyd and Crawford, 2012: 663). Rather, not only is data-even Big Data - incredibly partial and value laden, but it is also more than just a reflection, even a distorted one. Indeed, drawing on work on performativity we can say that data of all kinds does not simply capture the world as it actually is, but in the process of representing it, also transforms it. In his seminal analyses of the performative role of economics, Donald MacKenzie writes that "Financial economics... did more than analyze markets; it altered them. It was an 'engine'... an active force transforming its environment, not a camera passively recording it" (MacKenzie, 2006: 12). Indeed, the same can be said of any such mobilization of data, though the effects of the performativity of data are in many ways increasingly masked by an ideology that continues to frame data as an objective and valuefree way of assessing the world as it actually is. While similar currents of thought have long been applied to questions of mapping (cf. Harley, 1989), recent work by Aalbers (2014a) has explicitly brought together the approaches of critical cartography and performativity, arguing that "cartographers do not simply produce knowledge about geography; they produce geography through their observations and measurements. Mapping contributes to the making of geography rather than simply describing geography ... the act of mapping a place becomes part of shaping that place. Mapping performs, shapes and formats geography, rather than merely observing how it functions" (2014a: 532). That is, rather than simply shifting from seeing the map as a neutral transmitter of information to seeing the map as the product of power relations (cf. Crampton, 2001), the performativity thesis argues, in effect, that "it is the map that precedes the territory" (Baudrillard, 1994: 1).

As MacKenzie and others argue, "It is not (only) about economics being 'right' or 'wrong' but (also, and perhaps more important) about it being 'able' or 'unable' to transform the world" (MacKenzie et al., 2007: 2). Again, the same can be said for how datadriven analyses construct new understandings of the urban; it is less important that these analyses be correct or comprehensive, per se, but rather that through such analyses, these technologies (and the systems of human knowledge organized around them) enable a particular way of seeing social processes and understanding them 
as problems to be (and that can be) solved. While much of the literature on the performativity of economics focuses on how ostensibly detached scholarly knowledge about the economy has come to influence the actual practices and functioning of the economy, my focus here is not exclusively on the construction of the urban by scholars, though that is certainly a part of it. Given that one feature of the ongoing 'data revolution' is a blurring of the boundaries between academic, industry and governmental knowledges through the widespread application of data to a variety of problems, any analytical separation between these spheres is tenuous at best. As such, the two vignettes that follow explore ways that both scholarly interpretations of the urban, as well as more 'applied' or practical mobilizations of data to understand urban processes in fact work to construct the urban as we know it.

\section{The 'scientific' redefinition of the city}

Although much of the contemporary discourse around the application of Big Data to cities has focused on the role of multinational technology corporations active in the nascent smart cities industry (cf. Greenfield, 2013; Hollands, 2008, 2015; McNeill, 2015; Söderström et al., 2014, Viitanen and Kingston, 2014; Wiig, 2015), one of the more prominent examples of how Big Data has been mobilized to rethink the urban is in the form of the more academic 'new urban science' (cf. Townsend, 2015). Led largely by the likes of physicists and computer scientists working in new start-up academic research centers like NYU's Center for Urban Science and Progress or the University of Chicago's Urban Center for Computation and Data, this nascent academic field attempts to apply the analytical tools of the 'hard' sciences to what they see as the insufficiently 'scientific' field of urban studies. Though some more conventionally trained social scientists have attempted to push forward the call for a more 'scientific' approach to urban studies (cf. Solecki et al 2013 and Batty 2013, who has been arguing for such a scientific approach from within a more conventional geographic framework for several decades, or similar such calls being made a half-century ago by Berry 1964), arguably the most prominent boosters and exemplars of this approach have been the Santa Fe Instituteaffiliated physicists Geoffrey West and Luis Bettencourt. Thanks to the media-friendly packaging of their research as the search for a single 'universal law' of urbanization, West and Bettencourt's work has led to a New York Times profile in 2010, a feature on the popular NPR radio program RadioLab, a widely viewed TED Talk in 2011 and a range of other recurring media inquiries about urban issues in the years since.
Though much of the supporting discourse around this new urban science tends towards a hubristic dismissal of all previous scholarly research into cities and urban processes, such as the aforementioned work by mid-20th century quantitative geographers and urbanists like Berry and Batty, what is most important about their work from my perspective is that it highlights how the epistemological position associated with much of the conventional Big Data research leads directly to a particular ontological position about what the city actually is. For West and Bettencourt, the epistemological commitments of quantification require them to develop an ontology of the urban that is constrained entirely by that which is most easily counted. In their case, a range of relatively accessible (if geographically uneven) data on patents, crime, gross domestic product, and income (presumably among other things), points to the fundamental role of population size in determining the nature of the city. The city as imagined by urban science is one of, quite simply, little more than a mass of population. As Bettencourt and West say plainly, "size is the major determinant of most characteristics of a city; history, geography and design have secondary roles" (Bettencourt and West, 2010: 912). Though in one of several papers reporting on their research, they attempt to walk back these claims by saying that "population size is not so much a causal force" (Bettencourt et al., 2010: 6), such a statement pales in comparison to their repeated focus, even within the same paper, on arguing that "population size plays a fundamental role in this approach" (Bettencourt et al., 2010: 6), and even going as far as to admit that the entire research project is analytically predetermined to be about population: "Our primary analytical focus here was concerned with the consequences of population size on a variety of urban metrics" (Bettencourt et al., 2007: 7305) (Figure 1).

But the urban geographical imaginary developed by West and Bettencourt isn't defined entirely by population size, but also by universality. Throughout their published findings, West and Bettencourt are at pains to emphasize just how universal and fundamental their law of superlinear scaling is. There is, however, little to no reflection on how their theorizations are the result of unstated assumptions about geographic processes that are an artifact of their data collection procedures. In his widely viewed 2011 TED Talk, West claims that "This 15 percent rule is true no matter where you are on the planet-Japan, Chile, Portugal, Scotland, doesn't matter. Always, all the data shows it's the same, despite the fact that these cities have evolved independently. Something universal is going on" (West, 2011). It is unclear, however, whether the data West and Bettencourt mobilize actually substantiates such claims to universality. In one of their earlier papers 


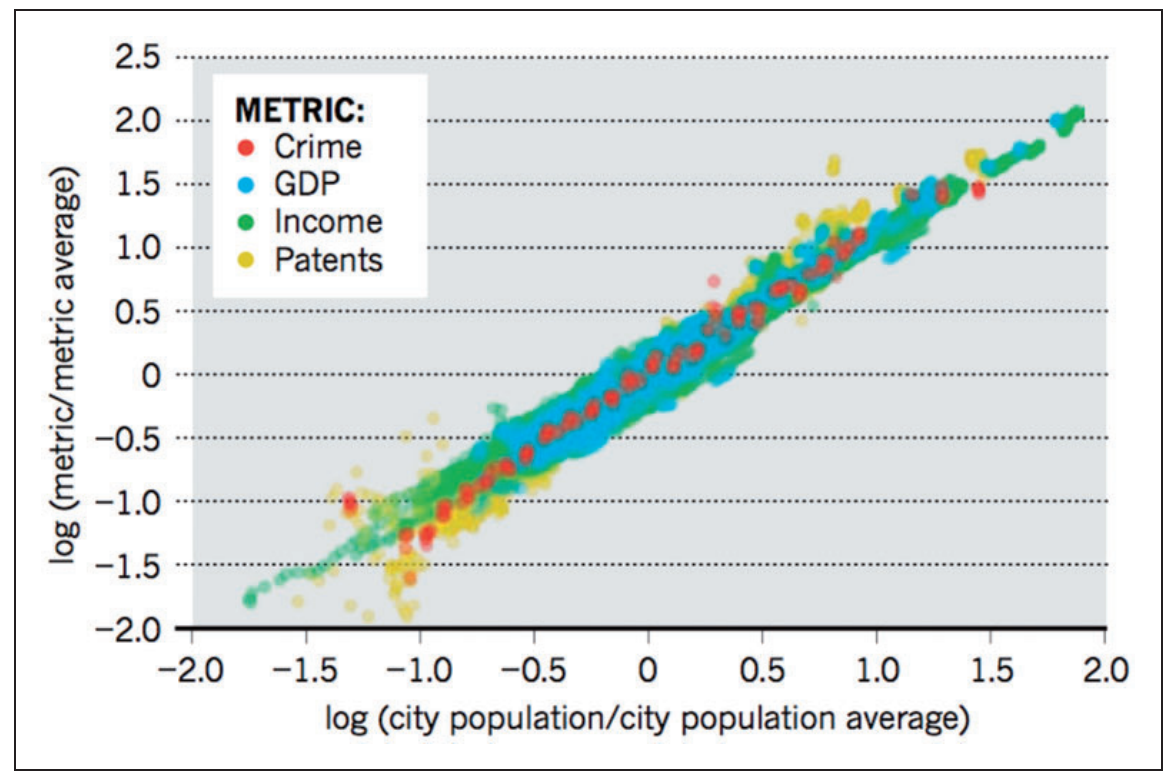

Figure I. Visualizing the law of urban scaling, from Bettencourt and West (2010).

on the subject, they described having "obtained datasets at this level of detail mostly for the US, where typically more data are available and in more particular cases for European countries and China" (Bettencourt et al., 2007: 7302), which would, at best, account for only about a third of the global population. It is unclear from their website and published papers whether data collection was entirely limited to these countries, or whether cities in Latin America, Africa, and Asia were also included, and if excluded, what impact these cities might have on the supposedly universal scaling laws. Paraphrasing a recent intervention by Susan Parnell and Edgar Pieterse (2016), "either [these places] must be ignored, or the theory, method and data of urban [science] must change" (p. 241). Similarly, through the use of statistics aggregated to either juridical or functional urban boundaries, West and Bettencourt fail to consider that the social processes embodied in their metrics may be geographically uneven within each city. For instance, in their invocation of patent registrations as a proxy measure for innovation, West and Bettencourt assume that such innovation is distributed equally across the city, rather than concentrated in particular sub-urban localities. The same could be said for their use of data on income, crime, pollution, and so on. Unless each of these variables corresponded appropriately with population aggregates at finer spatial resolutions, which is highly unlikely given the increasingly splintered nature of contemporary cities (cf. Graham and Marvin, 2001), the superlinear scaling ideal would seem to break down at any other scale of analysis, further suggesting that the theory itself seems to be more an artifact of the data used to create it than the objective identification of a fundamental socio-spatial process.

Borrowing from Timothy Mitchell, these flaws in West and Bettencourt's logical construction do not so much matter,

"Since these calculations were helping to bring into being the world they calculated, success d[oes] not necessarily depend on having the most accurate figures. What mattered more was whether the calculations enabled the network to be conceived and built... successful calculative devices are not necessarily those that are the most statistically complete or mathematically rigorous. They are those that make it possible to conceive of a network, or market, or national economy, or whatever is being designed, and assist in the practical work of bringing it into being" (Mitchell, 2008: 1118)

Indeed, West and Bettencourt's redefinition of the urban isn't important simply because of the attention it has gotten or its attempts to supersede existing urban theories, but because its understanding of what the urban actually is, in turn shapes the way we can understand what is and isn't possible in terms of policy interventions in important ways. Ultimately, the effect of West and Bettencourt's population-centric theory of urban scaling is a naturalization of the status quo. Echoing David Harvey's (1973 [2009]) early critiques of quantitative geography's valorization and naturalization of stylized models of urban land use, the logical result of arguing that the quintessential urban problems of wealth inequality, crime, pollution, and so on, are all directly tied to a single universal law or model — in this 
case, population size - is to say that there's nothing we can do to change these things.

When asked in an interview about the practical implications of their theories, West responded that "The scaling laws tell you that despite all of the efforts of planners, geographers, economists, architects, and politicians, and all of the local history, geography, and culture, somehow cities end up having to obey these scaling laws. We need to be aware of those forces when we design and redesign cities" (Greenwood, 2012). Or, as they argue in one of their earlier papers, "The realization that most urban indicators scale with city size nontrivially, implying increases per capita in crime or innovation rates and decreases on the demand for certain infrastructure, is essential to set realistic targets for local policy" (Bettencourt et al., 2007: 7306). That is, West and Bettencourt argue that all cities are, at their core, the same, and that there is nothing we can particularly do to change that fact. 'Realistic' in this sense would seem to mean an acceptance of such fundamental laws and a retreat from meaningful, substantive efforts to change them. Although West and Bettencourt's influence on broader urban debates isn't so great that planners and policymakers around the world are likely to abandon their efforts entirely and simply let cities run their 'natural' course, their redefinition of the urban as an essentially unchangeable biological organism provides a kind of cover or justification for the lack of meaningful improvements in urban life from what are, in most cases, neoliberal policy interventions. In a New York Times profile of West, it is said that West believes that "creating a more sustainable society will require our big cities to get even bigger" (Lehrer, 2010). It would seem to follow, however, that if we were to desire minimizing the range of negatives that come with increased city size, the only solution would not be to further grow cities, but to depopulate them, a fact that seems much more in tune with West's admittedly neo-Malthusian thinking (Greenwood, 2012). Regardless, such a laissez faire approach to urban policy remains grounded in a theoretical construct that is itself significantly the product of uneven, and in some cases potentially incommensurate, data, but which is widely accepted due to its appeals to the supposed objectivity and rationality inherent in Big Data analytics, and its ability to reinforce the contemporary policy status quo.

\section{Vacant property mapping and the (re)production of territorial stigma}

While the example of urban science's attempts to reshape our understandings of the urban at a macrolevel demonstrates how the data-driven urban geographical imagination is being produced in very public and visible ways, our understandings of the nature of urban space are also being shaped at finer spatial scales, and in much more mundane ways. In particular, I am interested in the mobilization of new web mapping tools to produce quick snapshots of different datasets on urban processes, which has allowed for a solidification of urban geographical imaginaries oriented around the idea of 'problem areas'. While this parlance is not particularly novel, through this phrasing I hope to draw attention to the double meaning of the 'problem area' and the increasingly important role of data in its construction: on the one hand, different actors and institutions are able to understand that urban social problems are 'of a place' and rooted in particular geographic contexts, while, on the other hand, simultaneously understanding particular places as defined through and by their association with these problems.

In many ways, the growth of simplistic map mashup visualizations is tied to an increasing awareness of the importance of geography to understanding social issues, and the growth of municipal data that is (or can be) explicitly georeferenced to particular places within the city. That is, these visualizations are the result of simultaneously social and technical processes. But these visualizations, and the kinds of questions that spur them on, are problematic in that they tend to treat social and spatial processes in isolation. Focusing on questions like "where is $x$ ?" or "where are the $y$ located?", reproduces the kind of 'spatial fetishism' long critiqued by geographers, defined as "the creation in the structure of spatial relationships of an autonomous determinant to history and human action separated from the structure of social relations and the production process that generates it" (Soja, 1980: 208). With particular reference to the issue of collecting and representing spatial data, Wilson (2011) argues that "the pervasiveness of counting in these kinds of urban data practices... fixates on the occurrence, while displacing the conditions of that occurrence. Counting decontextualizes. Counting does not remove meaning... counting matters too much" (865). That is, in simply focusing on mapping the locations and concentrations of $x$ or $y$ urban problem, these visualizations fail to attend to how these problems, and certainly any meaningful solution for them, goes beyond a set of latitude and longitude coordinates or a particular bounded spatial unit like a census tract or municipal boundary. As the geographer Nik Blomley has written, "Mapmaking and maplike visualizations play a central role in power relations and the construction of space, property, and social identity ... to help make possible the very idea of 'space' as an abstract category, separate from the processes by which it is portrayed" (2004: 54-55). 
To draw again on theories of performativity, the act of mapping a given urban problem doesn't necessarily produce a meaningful understanding of the problem, though it does, however, help to produce the problem itself, and particular understandings of space underlying it. In the case of vacant and abandoned properties in Louisville, Kentucky, a variety of public-facing mapping platforms help to construct a geographical imaginary of this problem as being in many ways synonymous with the city's predominantly poor and AfricanAmerican West End. Initially developed in the early 20 th century as a white, working-class suburban area, the West End underwent significant racial transition in the mid-20th century, due in large part to a combination of urban renewal programs targeting what were then predominantly black neighborhoods, as well as the widespread enforcement of housing desegregation laws in predominantly white areas for the first time. As Cummings and Price (1997) note, white flight from the West End resulted in a halving of the area's white population throughout the 1960s, and again through the 1970s, leading the West End to be, at present, approximately $80 \%$ African-American. While the West End has long been neglected by the municipal government, like countless other impoverished and majority-minority neighborhoods across the country, recent years have brought a renewed attention to the West End, and an attempt to address the so-called '9th Street Divide' that separates the West End from the rest of the city (Crutcher, 2013). When one prominent local urbanist was asked during a talk at a local historical society what issue he would tackle if he had a magic wand, he responded simply with "the West End", a comment important for simultaneously denoting the importance the area holds to the city's future, as well as for its synecdoche, or the way a variety of problems come to be represented in the figure of the West End as a whole.

One of the key means through which this attention to the West End has been focused is through Mayor Greg Fischer's initiative to address the growth of vacant and abandoned properties in the city, the majority of which are concentrated within the West End. In early 2013, Fischer articulated a goal of reducing the city's number of vacant and abandoned properties by $40 \%$ over three years, and $67 \%$ over five years (Bailey, 2013), and developed VAPStat, a spin-off of the city's much-touted LouieStat performance improvement program focused entirely on tracking, and publicly reporting on, the city's progress on meeting various goals related to the vacant properties campaign. Fischer even assigned key responsibilities for the vacant properties campaign to the city's Innovation Delivery Team, a group of experts funded by Bloomberg Philanthropies to introduce more 'innovative' approaches to municipal governments around the country, with a particular focus on the use of data to understand and solve problems facing municipal governments. As such, the question of vacant properties, and the West End more generally, became intimately intermingled with the city's broader focus on the use of new data sources and analytics. But the application of these data-driven and datacentric approaches to understanding vacant properties has not been entirely straightforward, as the tools being used to more rationally manage the problem also have a considerable hand in shaping the problem itself.

Beginning in early 2014, Louisville Metro Government partnered with the nascent technology company OpportunitySpace in order to serve as a test case for their platform, listing city-owned land bank properties as part of a government-sponsored 'Lots of Possibility' contest, in which innovative ideas for redeveloping vacant properties could be submitted for the chance to receive both the deed to a property and an additional grant to fund the proposed project (Louisville Metro Government, n.d.). OpportunitySpace is a web-based platform, developed by then-graduate students in Harvard's Kennedy School of Government, that aims to leverage municipal open data about vacant properties, especially those that are publicly owned through land banks, in order to stimulate private investment in these properties. OpportunitySpace allows users to sort or gather more information on these properties according to a range of characteristics: their size, location, cost, zoning classifications, etc. (see Figure 2), in order to make data that's technically publicly available more publicly accessible (Capps, 2014). And while some Metro government employees involved with the city's vacant properties campaign didn't see OpportunitySpace as providing the kind of single portal for property data that could rationalize the vacant property redevelopment process, they did see the platform as being potentially important for the ultimate goal of raising awareness about the city's struggle with vacant properties and drumming up interest in the Lots of Possibility competition and other government initiatives. That is, rather than providing a comprehensive information portal about vacant properties, OpportunitySpace sees itself as "reflect[ing] cities' proactive posture related to redevelopment" (Capps, 2014), focused primarily on the channeling of interest and energy related to these issues into the solution of market-based redevelopment of these properties.

And while the OpportunitySpace example is interesting in that it is tied explicitly to a particular set of interventions, perhaps more interesting is the visualization 


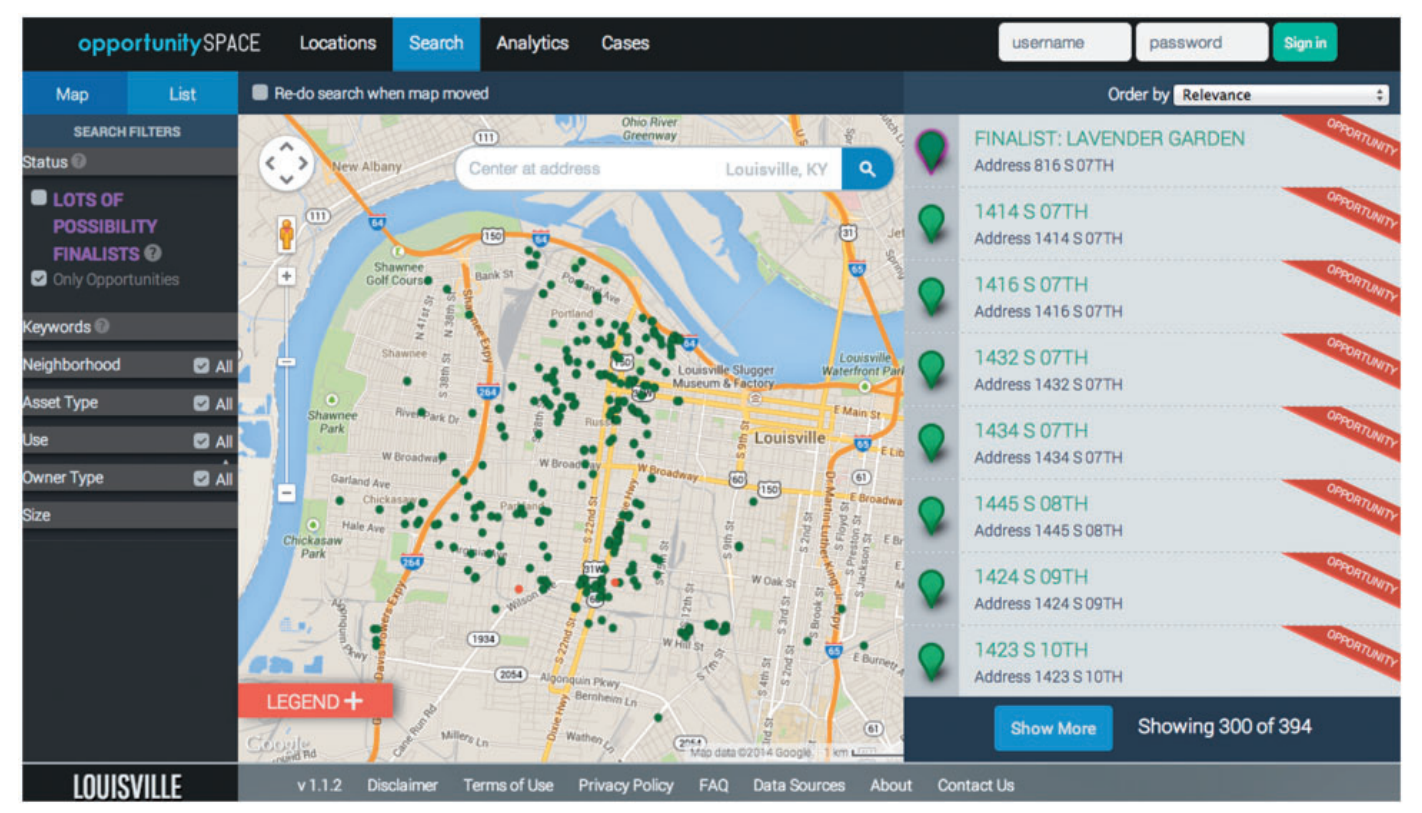

Figure 2. The OpportunitySpace Interface for Louisville.

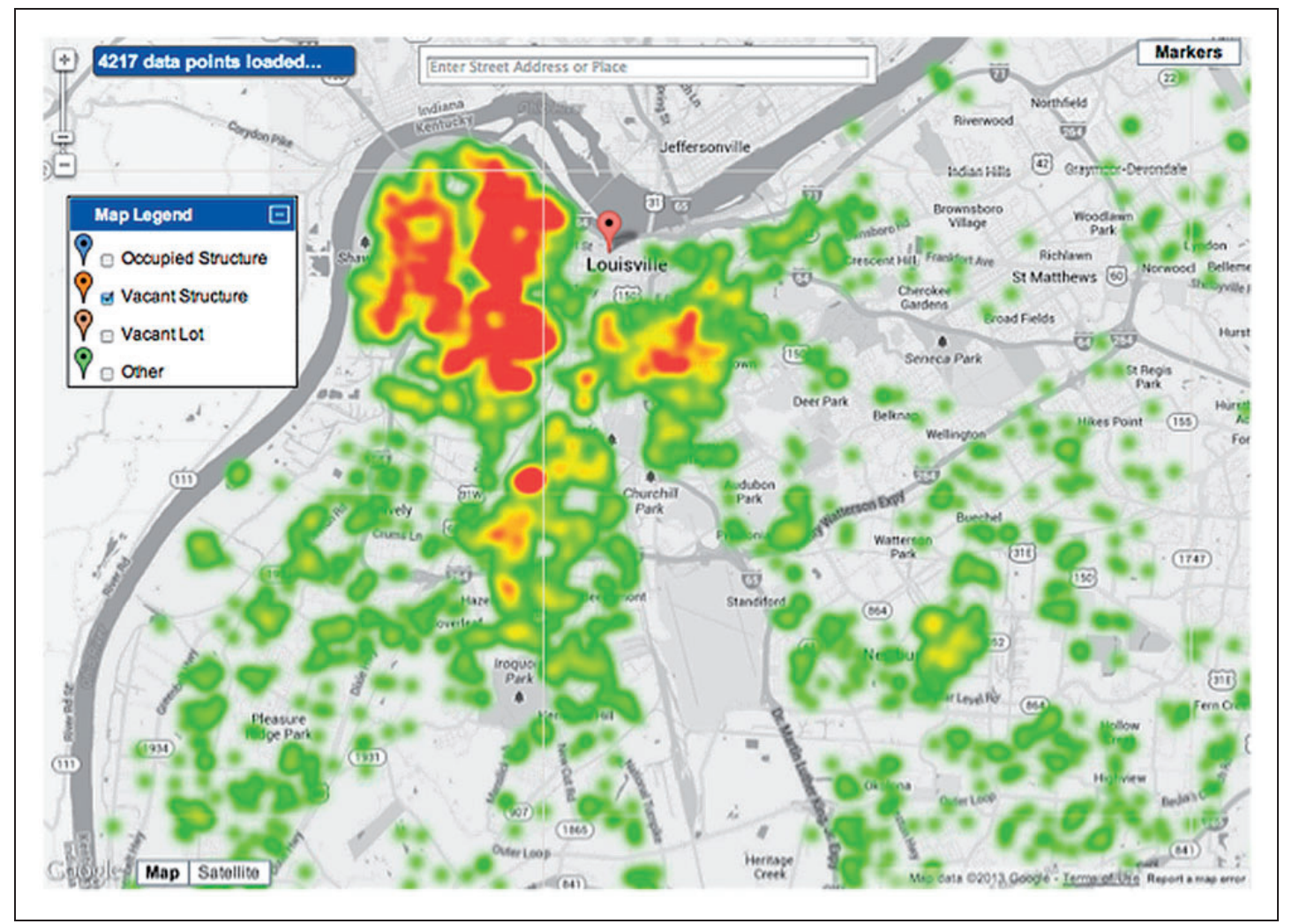

Figure 3. Heatmap of vacant properties in Louisville. 
of vacant properties seen in Figure 3. Taken from the Louisville Metro Government website - and lauded as a centerpiece of the city's vacant properties campaign (Louisville Metro Government, 2013) - this heatmap view of vacant properties provides arguably the most succinct visual summary of the geography of vacant properties in Louisville. While it is evident that the West End certainly isn't the only place in the city with concentrations of vacant properties, the map does make it clear that the problem is acutely concentrated west of 9th Street, a fact confirmed by analysis of open datasets provided by Louisville Metro. Though the properties listed in the OpportunitySpace database of landbank properties are more acutely concentrated in the West End neighborhoods of Portland, Russell and Park Hill, this city-produced heatmap seems to expand the scope of the problem to encompass practically the entire West End as a whole.

That being said, this map doesn't simply represent the geography of vacant properties in the city, but it also works to produce a particular, and I would argue overly simplistic, socio-spatial imaginary of inequality in Louisville, one that in turn re-produces the territorial stigma developed around the West End. Because the contours of the map place the most significant concentrations squarely within the conventional boundaries of the West End, the problem of vacant properties is quite easily extrapolated to be just one part of the broader problem presented by the West End and encapsulated in the imaginary of the 9th Street Divide. Even though these kinds of public-facing, interactive web map interfaces have been thought to provide an alternative form of knowledge politics, emphasizing a kind of "knowing through exploring [that] stands in contrast to the cartographic narratives approach that relies more upon a 'receive and believe' paradigm" (Elwood and Leszczynski, 2013: 554), I would argue that these cases of vacant property mapping in Louisville do anything but. Even though there always remains an open possibility of the same, ostensibly authoritative, map being interpreted differently by different people (cf. Elwood, 2006), the structuring of these maps, and the inability of users to contribute to, or reconfigure, or cross-reference the data being represented in these cases, tends to minimize such possibilities for alternative forms of knowledge production. Instead, following Elwood and Mitchell (2013), we can see these representations serving as sites for both "the formation of political subjects [and] the formation of interpretive frames that can mobilize these subjects for action", although in a manner that channels the map reader into a single interpretive frame, rather than allowing for a plurality of representations. In this case, these visualizations reinforce what Wacquant et al. call "the mistake of artificially insulating the poor in social space" (2014:
1271), reifying the 'blemish of place' associated with living in a predominantly poor and African-American area such as the West End. In effect, these kinds of visualizations implicitly blame the people living there for everything from redlining to property speculation and the foreclosure crisis that fed into the production of the city's vacant property problem, cordoning off such areas from their surrounding social and spatial context in order to understand them as somehow separate and apart from the rest of the city, despite the fact that many of these problems originate in the desires and actions of more affluent whites living elsewhere in the city (or even outside of it altogether). As Doreen Massey has written "How many times has the 'inner city problem' been 'explained' in terms of characteristics totally internal to those areas? - to a supposed lack of skilled labor, to the actions of planners, or, worst of all, to the psychological propensities and sociological characteristics of their inhabitants?" (Massey, 1979: 57).

By seeing these problems as restricted to a particular territory, and as the result of an engrained socio-spatial pathology, the logical solutions offered by civic leaders rarely, if ever, address the root causes of these problems. From larger scale projects like the building of a Wal-Mart and a methane biodigester plant in the area to the more piecemeal efforts associated with the Lots of Possibility competition and one local developer's artist-led gentrification of vacant shotgun houses in the Portland neighborhood, the reproduction of the 'reputational ghetto' becomes itself the impetus for particular kinds of 'revitalization' initiatives (Slater and Anderson, 2012). Indeed, contra Aalbers' (2014b) argument around the way that maps can prescribe policies of planned shrinkage and the withdrawal of services from already neglected urban areas, these maps actually promote more active engagements with the West End, albeit still in a way that tends to disempower existing residents in favor of outsiders with capital who are privileged in municipal decision-making processes.

But the use of data in order to map and track vacant properties in Louisville is less than straightforward. Despite Mayor Fischer's plan to reduce the number of vacant properties by a certain percentage at certain times, the actual numbers of vacant properties provided by the city have been described by some as "just guesses" that are divorced from the on-the-ground reality of the city's vacant properties problem (Carter, 2013). Because the classification of vacancy and abandonment by the Metro government relies on a series of discrete indicators, such as properties without water service, with unaddressed code violations or unpaid property taxes, there is a tendency to undercount the number of properties that may actually be vacant or 
abandoned at any given time. One community organization's on-the-ground participatory mapping project found that Metro government was underestimating the number of vacant properties in some neighborhoods by up to $80 \%$ (Katayama, 2012). And while more accurate or comprehensive counts of the city's vacant properties may only show the problem to be further concentrated in the West End, this contention over the actual way that vacant properties are counted in order to be mapped "highlights that data is never simply an objective representation of the world and always a possible forum for political contestation" (Shelton et al., 2015b: 18). It also further underscores a key element of the performativity thesis as applied to the question of the production of urban territories: data need not be entirely accurate in order to produce an actionable understanding of particular spaces and social processes.

Unlike the reimagining of the urban at the core of West and Bettencourt's new urban science, which naturalizes the status quo for the sake of non-intervention, these maps of vacant properties in Louisville seem to presuppose intervention by positioning the question of vacant properties as a kind of information problem. OpportunitySpace is explicitly conceived of as a way to encourage private investments in vacant and abandoned properties by providing otherwise difficultto-access information to potential investors. Importantly, however, OpportunitySpace isn't targeted at, for instance, the long-term residents of the West End who are surrounded by vacant properties and must live with their deleterious effects, but rather at a largely white, middle-class population from outside these neighborhoods who are able to capitalize on the longer-term disinvestment occurring in the West End in order to benefit themselves and realize their own visions for what the West End ought to look like. And though the Louisville Metro Government's heatmap of vacant properties is less directly tied to a particular kind of intervention, the reproduction of a socio-spatial imaginary that sees the West End as somehow separated from the rest of the city, as a kind of 'problem area', helps to justify practically any policy intervention into it, even if these interventions tend to address the symptoms or effects rather than the causes.

\section{Conclusion}

Ultimately, this paper has argued that despite the importance of Big Data as both a discourse and practice to emerging forms of urban research and management, there is no singular or universal understanding of the urban that is promoted or developed through the application of these new sources of data. Like contemporary conceptualizations of both the urban (Robinson and Roy, 2016) and Big Data (Kitchin and McArdle,
2016), more generally, the urban geographical imagination in the age of Big Data is complex, contradictory and highly variegated, operating across multiple scales through different kinds of interpersonal and institutional networks. Despite claims that "with enough data, the numbers speak for themselves" (Anderson, 2008), providing a single, optimal understanding of any given social phenomenon, the data-driven urban geographical imagination causes us to understand the city simultaneously as something both fundamentally unchangeable, as in the work of West and Bettencourt, and as something imminently interveneable (assuming we have access to the right information), as demonstrated by the case of vacant property mapping in Louisville. Setting aside the pervasive issues of data quality that are seen in both of the cases discussed above, this contradiction between the vision of data 'speaking for itself' and the reality of a plurality of voices emanating from different mobilizations of data, points towards a fundamental flaw in the belief that data necessarily leads to improved understandings of cities, or any other given phenomena. Regardless of these contradictions, there remains a general tendency in these particular strands of data-driven analysis to neglect the fundamental underlying processes at work, isolating the issue in question from broader social and spatial contexts that influence the outcomes of any given intervention. Despite Big Data's relationality - understood in this instance as the ability to combine and cross-reference disparate datasets-dominant usages and interpretations of such data remain fundamentally non-relational in the social sense, failing to identify or understand the connections between seemingly separate or isolated phenomena.

While these dominant data-driven imaginaries have largely failed to produce a substantively better understanding of urban processes, these kinds of intellectual projects have accomplished something akin to what Timothy Mitchell describes as the "transferr[al of] this knowledge to new sites... open[ing] up a certain distance, the distance between the field and the computing office, between the farmer and the colonial survey officer, between the iron triangulation marker and the paper map" (Mitchell, 2002: 92). That is, urban knowledge is increasingly removed from the urban itself, codified only in a series of quantifiable measures that allow for an increasingly detached, and putatively objective and scientific understanding of its true essence. As with earlier attempts to understand cities through scientific methods, it is unlikely that many of these experiments in applying Big Data to our understandings of the city will reveal previously unforeseen insights (Light, 2003). It is almost assured, however, that these new ways of studying and intervening in 
urban processes will reshape our conceptions of how cities ought to be understood and planned, resulting in a privileging of new forms of data and methods of analysis at the expense of more historically and geographically complex and grounded insights.

Of course, just as historical connections between quantitative methodologies, positivist epistemologies and reactionary politics were contingent circumstances (Wyly, 2009), so too is the contemporary constellation of smart cities, urban science, and other urban data initiatives. While the above vignettes highlight the ways that dominant mobilizations of data tend to depoliticize certain ways of understanding and intervening in urban spaces, many of the same sources of data and new mapping technologies offer significant potential for pushing back against such representations. From the speculative mappings of Neil Brenner's Urban Theory Lab (cf. Katsikis, 2014; Urban Theory Lab-GSD, 2013), which demonstrate the incredibly partial understanding of the urban promoted by the likes of West and Bettencourt, or attempts to connect the seemingly discrete, segregated spaces of Louisville's West End to the broader social and spatial context that gave rise to problems like those of vacant properties (cf. Shelton, 2015; Shelton et al., 2015a, 2015b, for more discussions of alternative mappings of the West End and the geographies of Louisville's vacant properties problem), mapping and data visualization maintains a significant potential for shaping more complex and emancipatory understandings of urban space. ${ }^{2}$ So while the production of the data-driven urban geographical imaginary may tend towards a kind of post-political naturalization of the contemporary urban condition, such an imaginary is in no way inherent or uncontested. Indeed, through the creative analysis and visualization of these new sources of data, alternative understandings and interventions can be proposed and pursued, potentially enabling more democratic and egalitarian ways of actually producing the urban as we know and experience it.

\section{Acknowledgements}

The author would like to thank Thomas Lodato, Ate Poorthuis, and three anonymous reviewers for their immensely helpful comments on earlier drafts of this paper.

\section{Declaration of conflicting interests}

The author(s) declared no potential conflicts of interest with respect to the research, authorship, and/or publication of this article.

\section{Funding}

The author(s) received no financial support for the research, authorship, and/or publication of this article.

\section{Notes}

1. The converse of this phenomena is explored in a recent article by and David O'Sullivan and Steven Manson (2015), in which they ask, "Do Physicists Have Geography Envy?".

2. Other recent examples of mapping and data visualization work that seeks to posit a more explicitly politicized understanding of the contemporary city include the work of the Anti-Eviction Mapping Project in California's Bay Area (www.antievictionmap.com) and the Property Praxis project in Detroit (www.propertypraxis.org).

\section{References}

Aalbers MB (2014a) Do maps make geography? Part 1: Redlining, planned shrinkage, and the places of decline. ACME: An International E-Journal for Critical Geographies 13(4): 525-556.

Aalbers MB (2014b) Do maps make geography? Part 2: PostKatrina New Orleans, post-foreclosure Cleveland and neoliberal urbanism. ACME: An International E-Journal for Critical Geographies 13(4): 557-582.

Anderson C (2008) The end of theory: The data deluge makes the scientific method obsolete. Wired Magazine 15(7). Available at: http://www.wired.com/2008/06/pb-theory/ (accessed 9 August 2016).

Bailey P (2013) City highlights progress on demolitions, foreclosures of vacant properties. WFPL 89.3fm. 10 January. Available at: http://wfpl.org/city-highlights-progressdemolitions-foreclosures-vacant-properties/ (accessed 9 August 2016).

Barns S (2016) Mine your data: Open data, digital strategies and entrepreneurial governance by code. Urban Geography 37(4): 554-571.

Barnes TJ (2013) Big Data, little history. Dialogues in Human Geography 3(3): 297-302.

Barnes TJ and Wilson MW (2014) Big Data, social physics, and spatial analysis: The early years. Big Data \& Society 1(1): 1-14.

Batty M (2012) Smart cities, Big Data. Environment and Planning B: Planning and Design 39(2): 191-193.

Batty M (2013) The New Science of Cities. Cambridge, MA and London, UK: MIT Press.

Batty M (2014) Can it happen again? Planning support, Lee's Requiem and the rise of the smart cities movement. Environment and Planning B: Planning and Design 41(3): 388-391.

Baudrillard J (1994) Simulacra and Simulation. Ann Arbor, MI: University of Michigan Press.

Berry BJL (1964) Cities as systems within systems of cities. Papers in Regional Science 13(1): 147-163.

Bettencourt LMA, Lobo J, Helbing D, et al. (2007) Growth, innovation, scaling, and the pace of life in cities. Proceedings of the National Academy of Sciences 104(17): 7301-7306.

Bettencourt LMA, Lobo J, Strumsky D, et al. (2010) Urban scaling and its deviations: Revealing the structure of wealth, innovation and crime across cities. PLoS ONE 5(11): e13541. 
Bettencourt L and West G (2010) A unified theory of urban living. Nature 467(7318): 912-913.

Blomley N (2004) Unsettling the City: Urban Land and the Politics of Property. New York, NY and London, UK: Routledge.

Boyd D and Crawford K (2012) Critical questions for Big Data: Provocations for a cultural, technological, and scholarly phenomenon. Information, Communication \& Society 15(5): 662-679.

Boyer MC (1986) Dreaming the Rational City: The Myth of American City Planning. Cambridge, MA and London, UK: MIT Press.

Brenner N and Schmid C (2014) The 'urban age' in question. International Journal of Urban and Regional Research 38(3): 731-755.

Brömmelstroet MT, Pelzer P and Geertman S (2014) Forty years after Lee's Requiem: Are we beyond the seven sins? Environment and Planning B: Planning and Design 41(3): 381-387.

Bulmer M (1981) Quantification and Chicago social science in the 1920s: A neglected tradition. Journal of the History of the Behavioral Sciences 17(3): 312-331.

Burgess E (1923) The growth of the city: An introduction to a research project. Publications of the American Sociological Society 18(1): 85-97.

Capps K (2014) A new portal to pair eager developers and underused properties. CityLab, 13 June. Available at: http://www.citylab.com/work/2014/06/a-portal-to-matchdistressed-public-properties-with-eager-developers/372722/ (accessed 9 August 2016).

Carter B (2013, 31 May) Louisville must determine number of vacant properties. Louisville Courier-Journal.

Crampton J (2001) Maps as social constructions: Power, communication and visualization. Progress in Human Geography 25(2): 235-252.

Crutcher D (2013, March) A tale of two cities. Louisville Magazine 25-29.

Cummings S and Price M (1997) Race relations and public policy in Louisville: Historical development of an urban underclass. Journal of Black Studies 27(5): $615-649$

Elwood S (2006) Beyond cooptation or resistance: Urban spatial politics, community organizations, and GIS-based spatial narratives. Annals of the Association of American Geographers 96(2): 323-341.

Elwood S and Leszczynski A (2013) New spatial media, new knowledge politics. Transactions of the Institute of British Geographers 38(4): 544-559.

Elwood S and Mitchell K (2013) Another politics is possible: Neogeographies, visual spatial tactics, and political formation. Cartographica 48(4): 275-292.

Fairfield JD (1994) The scientific management of urban space: Professional city planning and the legacy of progressive reform. Journal of Urban History 20(2): 179-204.

Ford G (1913) The city scientific. Engineering Record 67(May): 551-552.

Graham M and Shelton T (2013) Geography and the future of Big Data, Big Data and the future of geography. Dialogues in Human Geography 3(3): 255-261.
Graham S and Marvin S (2001) Splintering Urbanism: Networked Infrastructures, Technological Mobilities and the Urban Condition. London, UK and New York, NY: Routledge.

Greenfield A (2013) Against the Smart City. New York, NY: Do Projects.

Greenwood V (2012) Geoffrey West finds the physical laws embedded in human cities. Discover Magazine, 28 September. Available at: http://discovermagazine.com/ 2012/oct/21-geoffrey-west-finds-physical-laws-in-cities (accessed 9 August 2016).

Hall PA (2002) Cities of Tomorrow: An Intellectual History of Urban Planning and Design in the Twentieth Century. Malden, MA: Blackwell.

Halpern O, LeCavalier J, Calvillo N, et al. (2013) Test-bed urbanism. Public Culture 25(270): 272-306.

Harley JB (1989) Deconstructing the map. Cartographica 26(2): 1-20.

Harvey D (1973 [2009]) Social Justice and the City. Athens, GA and London, UK: University of Georgia Press.

Hollands RG (2008) Will the real smart city please stand up? Intelligent, progressive or entrepreneurial? City 12(3): 303-320.

Hollands RG (2015) Critical interventions into the corporate smart city. Cambridge Journal of Regions, Economy and Society 8(1): 61-77.

Katayama D (2012) Louisville doesn't do good enough job tracking vacant properties, report says. WFPL 89.3fm 29 November. Available at: http://wfpl.org/louisville-doesntdo-good-enough-job-tracking-vacant-properties-reportsays/ (accessed 9 August 2016).

Katsikis N (2014) On the geographical organization of world urbanization. MONU 20: 4-11.

Kitchin R (2014) The real-time city? Big Data and smart urbanism. GeoJournal 79(1): 1-14.

Kitchin R and McArdle G (2016) What makes Big Data, Big Data? Exploring the ontological characteristics of 26 datasets. Big Data \& Society 3(1): 1-10.

Lee DB (1973) Requiem for large-scale models. Journal of the American Institute of Planners 39(3): 163-178.

LeGates R, Tate NJ and Kingston R (2009) Spatial thinking and scientific urban planning. Environment and Planning B: Planning and Design 36(5): 763-768.

Lehrer J (2010) A physicist turns the city into an equation. The New York Times, 17 December. Available at: http:// www.nytimes.com/2010/12/19/magazine/19Urban_West-t. html (accessed 9 August 2016).

Leitner H and Sheppard E (2016) Provincializing critical urban theory: Extending the ecosystem of possibilities. International Journal of Urban and Regional Research 40(1): 228-235.

Leszczynski A (2016) Speculative futures: Cities, data, and governance beyond smart urbanism. Environment and Planning A 48(9): 1691-1708.

Light JS (2003) From Warfare to Welfare: Defense Intellectuals and Urban Problems in Cold War America. Baltimore, MD and London, UK: Johns Hopkins University Press.

Louisville Metro Government (n.d.) Lots of possibility. Available at: https://louisvilleky.gov/government/vacant- 
public-property-administration/lots-possibility (accessed 9 August 2016).

Louisville Metro Government (2013) City makes steady progress on vacant properties. Press Release, 10 January. Available at: http://www.lanereport.com/17394/2013/01/ vacant-properties-in-louisville/ (accessed 9 August 2016).

MacKenzie D (2006) An Engine, Not a Camera: How Financial Models Shape Markets. Cambridge, MA and London, UK: MIT Press.

MacKenzie DA, Muniesa F and Siu L (2007) Do Economists Make Markets?: On the Performativity of Economics. Princeton, NJ and Oxford, UK: Princeton University Press.

Massey D (1979) In what sense a regional problem? Regional Studies 13(2): 233-243.

Massey D (1999) Space-time, 'science' and the relationship between physical geography and human geography. Transactions of the Institute of British Geographers 24(3): 261-276.

McNeill D (2015) Global firms and smart technologies: IBM and the reduction of cities. Transactions of the Institute of British Geographers 40(4): 562-574.

Mitchell T (2002) Rule of Experts: Egypt, Techno-Politics, Modernity. Berkeley and Los Angeles, CA, and London, UK: University of California Press.

Mitchell T (2008) Rethinking economy. Geoforum 39(3): 1116-1121.

O'Sullivan D and Manson SM (2015) Do physicists have geography envy? And what can geographers learn from it? Annals of the Association of American Geographers 105(4): 704-722.

Park R (1936) Human ecology. American Journal of Sociology 42(1): 1-15.

Parnell S and Pieterse E (2016) Translational global praxis: rethinking methods and modes of African urban research. International Journal of Urban and Regional Research 40(1): 236-246.

Peck J (2016) Economic rationality meets celebrity urbanology: Exploring Edward Glaeser's city. International Journal of Urban and Regional Research 40(1): 1-30.

Porter TM (1996) Trust in Numbers: The Pursuit of Objectivity in Science and Public Life. Princeton, NJ: Princeton University Press.

Robinson J and Roy A (2016) Global urbanisms and the nature of urban theory. International Journal of Urban and Regional Research 40(1): 181-186.

Rose-Redwood R (2012) With numbers in place: Security, territory, and the production of calculable space. Annals of the Association of American Geographers 102(2): 295-319.

Schultz SK and McShane C (1978) To engineer the metropolis: Sewers, sanitation, and city planning in latenineteenth-century America. The Journal of American History 65(2): 389-411.

Scott AJ and Storper M (2015) The nature of cities: The scope and limits of urban theory. International Journal of Urban and Regional Research 39(1): 1-15.
Scott JC (1998) Seeing Like a State: How Certain Schemes to Improve the Human Condition Have Failed. New Haven, CT: Yale University Press.

Shelton T (2015) No vacant property is an island: Geographies of vacancy in Louisville and why we should care. Broken Sidewalk, 2 June. Available at: http://brokensidewalk.com/2015/no-vacant-property-is-an-island/ (accessed 9 August 2016).

Shelton T, Poorthuis A and Zook M (2015a) Social media and the city: Rethinking urban socio-spatial inequality using user-generated geographic information. Landscape and Urban Planning 142: 198-211.

Shelton T, Zook M and Wiig A (2015b) The 'actually existing smart city.' Cambridge Journal of Regions, Economy and Society 8(1): 13-25.

Sheppard E (2001) Quantitative geography: Representations, practices, and possibilities. Environment and Planning D: Society and Space 19(5): 535-554.

Slater T and Anderson N (2012) The reputational ghetto: Territorial stigmatisation in St Paul's, Bristol. Transactions of the Institute of British Geographers 37(4): 530-546.

Söderström O, Paasche T and Klauser F (2014) Smart cities as corporate storytelling. City 18(3): 307-320.

Soja EW (1980) The socio-spatial dialectic. Annals of the Association of American Geographers 70(2): 207-225.

Solecki W, Seto KC and Marcotullio PJ (2013) It's time for an urbanization science. Environment: Science and Policy for Sustainable Development 55(1): 12-17.

Townsend A (2015) Cities of data: Examining the new urban science. Public Culture 27(2): 201-212.

Urban Theory Lab-GSD (2013) Visualizing an urbanized planet-materials. In: Brenner $\mathrm{N}$ (ed) Implosions/ Explosions: Towards a Study of Planetary Urbanization. Berlin, Germany: Jovis, pp. 460-475.

Viitanen J and Kingston R (2014) Smart cities and green growth: Outsourcing democratic and environmental resilience to the global technology sector. Environment and Planning A 46(4): 803-819.

Wacquant L, Slater T and Pereira VB (2014) Territorial stigmatization in action. Environment and Planning A 46(6): 1270-1280.

West G (2011) The surprising math of cities and corporations. TED. Available at: https://www.ted.com/talks/geoffrey_ west_the_surprising_math_of_cities_and_corporations (accessed 9 August 2016).

Wiig A (2015) IBM's smart city as techno-utopian policy mobility. City 19(2-3): 258-273.

Wilson MW (2011) Data matter(s): Legitimacy, coding, and qualifications-of-life. Environment and Planning D: Society and Space 29(5): 857-872.

Wyly E (2009) Strategic positivism. The Professional Geographer 61(3): 310-322.

This article is a part of special theme on Urban Governance. To see a full list of all articles in this special theme, please click here: http://journals.sagepub.com/page/bds/collections/urban-governance. 